\title{
Biochar affects soil organic matter cycling and microbial functions but does not alter microbial community structure in a paddy soil
}

\author{
Jing Tian ${ }^{\mathrm{a}, *, 1}$, Jingyuan Wang a,1, Michaela Dippold ${ }^{\mathrm{b}}$, Yang Gao a , \\ Evgenia Blagodatskaya b,c,*, Yakov Kuzyakov b,d
}

a Key Laboratory of Ecosystem Network Observation and Modeling, Institute of Geographic Sciences and Natural Resources Research, Chinese Academy of Sciences (CAS), 100101 Beijing, China

${ }^{\mathrm{b}}$ Department of Soil Science of Temperate Ecosystems, University of Göttingen, 37077 Göttingen, Germany

c Institute of Physicochemical and Biological Problems in Soil Science, Russian Academy of Sciences, 142290 Pushchino, Russia

d Department of Agricultural Soil Science, University of Göttingen, 37077 Göttingen, Germany

\section{H I G H L I G H T S}

- $\mathrm{BC}$ addition increased total soil $\mathrm{C}$ and POC for $47.4-50.4 \%$ and $63.7-74.6 \%$, respectively:

- Addition of BC altered the microbial community structure in conjunction with NPK fertilization;

- BC addition increased microbial utilization of amino acids and amines.
G R A P H I C A L A B S T R A C T

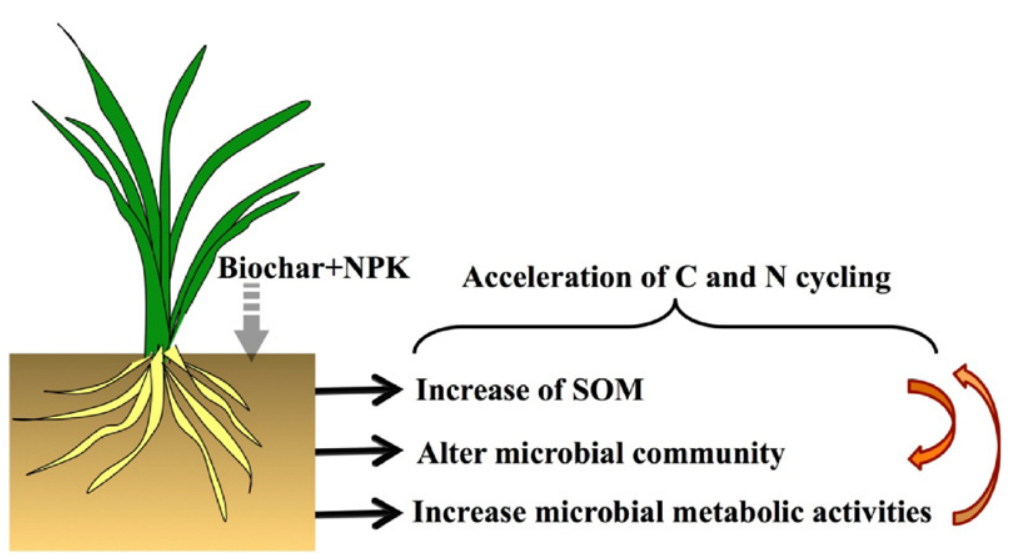

\section{A R T I C L E I N F O}

\section{Article history:}

Received 1 December 2015

Received in revised form 2 March 2016

Accepted 2 March 2016

Available online 12 March 2016

Editor: Jay Gan

\section{Keywords:}

Biochar

Soil organic matter fraction

Microbial community

\begin{abstract}
A B S T R A C T
The application of biochar (BC) in conjunction with mineral fertilizers is one of the most promising management practices recommended to improve soil quality. However, the interactive mechanisms of $\mathrm{BC}$ and mineral fertilizer addition affecting microbial communities and functions associated with soil organic matter (SOM) cycling are poorly understood. We investigated the SOM in physical and chemical fractions, microbial community structure (using phospholipid fatty acid analysis, PLFA) and functions (by analyzing enzymes involved in C and N cycling and Biolog) in a 6-year field experiment with BC and NPK amendment. BC application increased total soil C and particulate organic $C$ for $47.4-50.4 \%$ and $63.7-74.6 \%$, respectively. The effects of $\mathrm{BC}$ on the microbial community and C-cycling enzymes were dependent on fertilization. Addition of BC alone did not change the microbial community compared with the control, but altered the microbial community structure in conjunction with NPK fertilization. SOM fractions accounted for $55 \%$ of the variance in the PLFA-related microbial community structure. The particulate organic $\mathrm{N}$ explained the largest variation in the microbial community structure. Microbial metabolic activity strongly increased after BC addition, particularly the utilization of amino acids and amines due to an
\end{abstract}

\footnotetext{
* Corresponding authors at: J. Tian, Key Laboratory of Ecosystem Network Observation and Modeling, Institute of Geographic Sciences and Natural Resources Research, Chinese Academy of Sciences (CAS), 100101, Beijing, China; E. Blagodatskaya, Department of Soil Science of Temperate Ecosystems, University of Göttingen, 37077 Göttingen, Germany. E-mail addresses: tianj@igsnrr.ac.cn (J. Tian), janeblag@mail.ru (E. Blagodatskaya).

1 These authors contributed equally to this work.
} 
Enzymes

Microbial function increase in the activity of proteolytic (L-leucine aminopeptidase) enzymes. These results indicate that microorganisms start to mine $\mathrm{N}$ from the SOM to compensate for high C:N ratios after BC application, which consequently accelerate cycling of stable N. Concluding, BC in combination with NPK fertilizer application strongly affected microbial community composition and functions, which consequently influenced SOM cycling.

\section{Introduction}

Microorganisms mediate many processes, including soil organic matter (SOM) cycling and carbon (C) sequestration (Balser and Firestone, 2005; Clemmensen et al., 2013). The addition of biochar (BC) to soil is likely to feedback on ecosystem SOM and nutrient cycling by affecting the composition and function of microorganisms (Lehmann et al., 2011). However, the mechanisms by which BC application affects SOM dynamics via microorganisms remain unclear (Gul et al., 2015).

The addition of BC to soil can increase the SOM level (Lehmann et al., 2006), affect C cycling (Bolan et al., 2012; Farrell et al., 2015; Liang et al., 2010), accelerate nitrogen (N) dynamics (Nelissen et al., 2012) or in some cases, even reduce organic $\mathrm{N}$ turnover (Prommer et al., 2014). The changes in the total SOM due to management practices are gradual because SOM is a heterogeneous mixture that contains numerous compounds varying degradability and turnover rates (Stevenson, 1994). Therefore, studying individual SOM fractions separated by physical and chemical methods is a more informative practice, especially for the study of nutrient cycling (von Lützow et al., 2007). SOM fractions have been suggested as more sensitive indicators of the effects of management practices and soil disturbance than the total SOM (Haynes, 2005). The addition of BC to soil can differentially affect individual SOM fractions. For example, BC amendment increased the dissolved organic $C$ content (DOC), microbial biomass $C$ and light fraction organic $C$ compared with un-amended soil (Demisie et al., 2014; Lin et al., 2012). Specifically, the microbial biomass was up to $43-125 \%$ higher in BC-rich soils than in BC-poor adjacent soils during 532 days of incubation (Liang et al., 2010). On the contrary, BC amendment did not affect the DOC and dissolved organic N (DON) in one field study (Jones et al., 2012), whereas it decreased the DOC concentration (Prommer et al., 2014) in another field study. These contradicting positive and negative effects of BC application on SOM fractions may be attributed to the specific processes governing $\mathrm{C}$ and $\mathrm{N}$ cycling under specific management practices. These processes vary with climate, crop rotation, fertilization and soil biology characteristics and consequently result in inconsistent SOM dynamics and transformation (Demisie et al., 2014; Jones et al., 2012; Lin et al., 2012; Liang et al., 2010; Prommer et al., 2014).

Microorganisms are actively involved in SOM dynamics and transformation in terms of mineralization and formation (Bowles et al., 2014; Ng et al., 2014). After BC addition, greater decomposition of soil SOC was observed, accompanied by a higher microbial activity (Wardle et al., 2008) or changes in the microbial community (Farrell et al., 2013). On the other hand, BC addition suppressed SOC decomposition with altered microbial community structure by increasing Grampositive bacteria in a 30-day incubation study (Lu et al., 2014). The addition of BC altered C sources use patterns of microorganisms, perhaps via changes in the microbial population (Pietikäinen et al., 2000). All these studies suggested that SOM cycling might be influenced via microorganisms after $\mathrm{BC}$ addition. A number of studies reported changes in the microbial community after $\mathrm{BC}$ addition that were attributed to the physico-chemical properties of $\mathrm{BC}$ (e.g., aeration, sorption), as well as BC-induced changes in soil properties such as pH (Gul et al., 2015; Jindo et al., 2012; Rillig et al., 2010; Xu et al., 2014). However, information on microbial communities associated with soil SOM dynamics related to BC amendment is particularly limited (Gul et al., 2015). Furthermore, the majority of $\mathrm{BC}$ studies have relied on short-time incubation experiments (Farrell et al., 2013; Pietikäinen et al., 2000; Xu et al., 2014). Long-term field trials examining organic C- and N-related effects of $\mathrm{BC}$ on microorganisms still remain to be studied. As such studies will help us understand the role of environmental factors in controlling biochar-induced changes in soil chemical and biological properties.

In field studies, $\mathrm{N}$ is an important nutrient for maintaining crop yield. Because BC is generally low in inorganic $\mathrm{N}$, it is usually applied in conjunction with mineral fertilizer (Chen et al., 2013). In fact, the combination of $\mathrm{BC}$ and mineral fertilizers has been shown to synergistically affect crop yield and growth in field studies (Atkinson et al., 2010; Lehmann et al., 2003; Steiner et al., 2007). In addition to the possible effects of $\mathrm{BC}$ on microorganisms described above, the combination of fertilizer and BC may also affect microorganisms in field studies (via direct mineral nutrient input or indirect crop effects). However, whether BC amendment affects microorganisms and SOM alone or synergistically with fertilizer remains unclear in field studies. Thus, long-term field trials examining the effects of $\mathrm{BC}$ and fertilizer on microbial community structure and SOM cycling are urgently needed.

We hypothesized that (1) BC and mineral fertilizer synergistically affect microbial community structure and activities because fertilization will directly and indirectly decrease possible nutrient limitation after $\mathrm{BC}$ addition; and (2) these changes in microbial community composition and function will alter SOM cycling. To test our hypothesis, we studied the effects of BC and mineral fertilizer on SOM and its fractions, microbial community structure (using phospholipid fatty acid analysis, PLFA) and functions (by analyzing enzymes involved in $\mathrm{C}$ and $\mathrm{N}$ cycling and Biolog) in a long-term field study.

\section{Materials and methods}

\subsection{Study site and field experiment}

A 6-year field study of a rice paddy was started in 2009 at Qianyanzhou ecological station in southern China $\left(26^{\circ} 44^{\prime} \mathrm{N}\right.$ and $115^{\circ} 03^{\prime} \mathrm{E}$ ), which belongs to the Chinese Academy of Science (CAS). The regional climate is classified as warm and humid with a mean annual temperature of $18{ }^{\circ} \mathrm{C}$ and precipitation of $1470 \mathrm{~mm}$. The soil has a heavy loam texture of $22.8 \%$ sand, $61.4 \%$ silt and $15.7 \%$ clay. The basic soil characteristics at the start of the field experiment were as follows: $6.6 \mathrm{~g} \mathrm{~kg}^{-1}$ SOC content, $0.7 \mathrm{~g} \mathrm{~kg}^{-1} \mathrm{TN}$ content, $33.9 \mathrm{mg} \mathrm{kg}^{-1}$ Olsen-P, and a soil $\mathrm{pH}$ of 4.9 .

Four treatments were laid out in a randomized complete block design in triplicate: control (CK), compound fertilizer (NPK) application, BC application (BC), and combined NPK fertilizer and BC application (BC-NPK). Each plot was $9 \mathrm{~m}^{2}$ in size. The compound chemical fertilizer application rate was $750 \mathrm{~kg} \mathrm{ha}^{-1}$, which was equivalent to $112.5 \mathrm{~kg} \mathrm{~N} \mathrm{ha}^{-1}, 49.1 \mathrm{~kg} \mathrm{P} \mathrm{ha}^{-1}$ and $93.4 \mathrm{~K} \mathrm{~kg} \mathrm{ha}^{-1}$. The BC was applied at $6 \mathrm{t} \mathrm{ha}^{-1}$ per year. The applied $6 \mathrm{t} \mathrm{ha} \mathrm{a}^{-1}$ per year corresponded to twice of the amount of rice biomass that could be produced in the field. The BC used in this experiment was made from pine wood via pyrolysis at a temperature of $450{ }^{\circ} \mathrm{C}$ for $8 \mathrm{~h}$ in a closed container under oxygenlimited conditions. The BC was crushed to particle sizes smaller than $2 \mathrm{~mm}$ before application to the soils. The BC contained $653 \mathrm{~g} \mathrm{C} \mathrm{kg}^{-1}$ and $3.9 \mathrm{~g} \mathrm{~N} \mathrm{~kg}^{-1}$.

\subsection{Soil sampling}

After the rice harvest in autumn 2014, soil was sampled from each plot by collecting 5 randomly selected cores (0-20 cm deep), which were mixed to yield one composite sample per plot. The samples were 
then stored in airtight polypropylene bags, placed in a cooler box at approximately $4{ }^{\circ} \mathrm{C}$ and transported to the laboratory. The leaves, roots and rock fragments were carefully removed, and the remaining soil samples were divided into several subsamples. Subsamples for microbial metabolic function, enzymes activities and dissolved organic matter (DOM) concentration analyses were stored at $4{ }^{\circ} \mathrm{C}$ for no longer than one week before finishing the analyses. Subsamples for SOM and particulate organic matter (POM) analyses were air dried at room temperature. The subsamples for the microbial community analysis were stored at $-80^{\circ} \mathrm{C}$.

\subsection{Soil SOM fractions analysis}

The total $\mathrm{C}$ and total $\mathrm{N}$ content in the soil was measured by dry combustion using a Vario Max CN elemental analyzer (Elementar, Germany).

The $\mathrm{C}$ and $\mathrm{N}$ concentrations in the DOM were measured following the method of Jones and Willett (2006). Eight grams of dry-weightequivalent fresh soil was extracted with $40 \mathrm{ml}$ of $0.05 \mathrm{~mol} \mathrm{~L}^{-1} \mathrm{~K}_{2} \mathrm{SO}_{4}$ (soil/solution ratio 1:4) for $1 \mathrm{~h}$. The extract was then passed through a $0.45-\mu \mathrm{m}$ membrane filter and analyzed for $\mathrm{C}$ and total dissolved $\mathrm{N}$ using a Multi 3100 N/C TOC analyzer (Analytik Jena, Germany). The concentrations of $\mathrm{NH}_{4}^{+}$and $\mathrm{NO}_{3}^{-}$in the subsamples were analyzed using an auto-analyzer (TRAACS-2000, BRAN + LUEBBE, Germany); the DON was determined by calculating as the difference between the total dissolved $\mathrm{N}$ and the combined $\mathrm{NH}_{4}^{+}$and $\mathrm{NO}_{3}^{-}$content.

The particulate organic $\mathrm{C}$ and particulate organic $\mathrm{N}$ (POC and PON) content were determined using the method described by Cambardella and Elliott (1992). Twenty grams of air-dried soil $(<2 \mathrm{~mm})$ was dispersed in $100 \mathrm{ml}$ of sodium hexametaphosphate $\left(\left(\mathrm{NaPO}_{3}\right)_{6}\right)\left(5 \mathrm{~g} \mathrm{~L}^{-1}\right)$. The sample was then first shaken by hand for $10 \mathrm{~min}$, followed by shaking on a reciprocating shaker ( $180 \mathrm{rpm} \mathrm{min}^{-1}$ ) for $18 \mathrm{~h}$. The soil suspension was poured over a $53-\mu \mathrm{m}$ sieve using a flow of distilled water. All material remaining on the sieve, which was defined as the particulate organic matter (POM), was washed into a dry dish, oven dried at $65^{\circ} \mathrm{C}$, weighed, ball-milled and analyzed for $\mathrm{C}$ and $\mathrm{N}$ by dry combustion using a Vario Max CN elemental analyzer (Elementar, Germany).

\subsection{Soil microbial community structure analysis}

The microbial community was determined using a PLFA analysis described by Frostegård et al. (1991) with modifications. The fatty acids were extracted with $8 \mathrm{~g}$ of dry-weight-equivalent fresh soil using a onephase extraction mixture containing chloroform:methanol:phosphate buffer. The amounts of fatty acid methyl esters (FAMEs) were analyzed on a GC-MS (TRACE GC Ultra ISQ). The individual compounds were identified by comparing their relative retention times to commercially available 37 FAMEs (FAME 37 47885-U, Supelco, Inc.) and a mixture of 26 bacterial FAMEs (BAME 26 47080-U, Supelco, Inc.). The individual compounds were quantified based on an internal standard.

We divided 4 microbial groups: Gram-positive (i14:0, i15:0, a15:0,

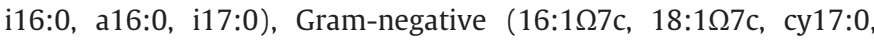
cy19:0), fungi (18:2 $\Omega 6,9 \mathrm{c}$ ) and actinomycetes (10Me17:0, 10Me18:0) based on previous studies (Bossio and Scow, 1998; Frostegård et al., 1993; Zelles, 1997; Zelles, 1999).

\subsection{Soil microbial metabolic function analysis}

The microbial metabolic function was characterized using the Biolog Eco-plate, which contained three replicate sets of 31 substrates (Garland and Mills, 1991). These substrates are associated with plant root exudates and can be divided into six groups: carbohydrates, amino acids, carboxylic acids, amines, polymers and miscellaneous (Preston-Mafham et al., 2002). Though it represents certain metabolic functions in the Micro-Plates, Biolog Micro-Plate breathprint reflects diversity of carbon-oxidation pathways, and therefore functional diversity of soil microbial communities (Preston-Mafham et al., 2002). Briefly, $10 \mathrm{~g}$ of fresh soil was added to $90 \mathrm{ml}$ of sterilized $\mathrm{NaCl}$ solution $(0.85 \%)$ and shaken at $200 \mathrm{rpm} \mathrm{min}^{-1}$ for $30 \mathrm{~min}$. Ten-fold serial dilutions were prepared, and each well of the Biolog Eco-plates was inoculated with $150 \mu \mathrm{L}$ of the suspension. The plates were incubated at $30{ }^{\circ} \mathrm{C}$ for 10 days, and the color development was assessed by measuring the absorbance every $24 \mathrm{~h}$ with an automated plate reader (VMAX, Molecular Devices, Crawley, UK) at a wavelength of $590 \mathrm{~nm}$.

The $72 \mathrm{~h}$ absorbance values were used to calculate the average well color development (AWCD), which indicates the microbial metabolic activity. The AWCD was determined as follows (Garland and Mills, 1991):

$\mathrm{AWCD}=\sum(\mathrm{Ci}-\mathrm{r}) / 31$

where $\mathrm{Ci}$ is the absorbance of each well, and $\mathrm{r}$ is the comparable absorbance of the control well (water in control well). Negative (Ci-r) values were set to zero.

The $72 \mathrm{~h}$ absorbance values were also analyzed to calculate the catabolic diversity (Shannon-Weiner diversity index, $\mathrm{H}^{\prime}$ ) (Zak et al., 1994). The microbial community functional diversity indicated by the Shannon-Weiner diversity index was calculated as follows:

$\mathrm{H}^{\prime}=\sum$ pi lnpi

where pi $=(C i-r) / \sum(\mathrm{Ci}-\mathrm{r})$.

\subsection{Soil enzyme assays}

The activities of five enzymes involved in $\mathrm{C}$ and $\mathrm{N}$ cycling in the soil were measured: $\beta$-1,4-glucosidase ( $\beta G), \beta-1,4$-xylosidase ( $\beta X)$, cellobiohydrolase (CBH), $\beta-1,4-N$-acetylglucosaminidase (NAG) and Lleucine aminopeptidase (LAP). The following enzyme substrates, which were based on 4-methylumbelliferone (MUF), were used to assess the enzymatic activities: 4-MUB- $\beta$-D-glucoside for $\beta G$, 4-MUB- $\beta$ D-xyloside for $\beta X$, 4-MUB- $N$-acety1- $\beta$-D-glucosaminide for NAG, 4MUB- $\beta$-D-cellobioside for $\mathrm{CBH}$ and L-leucine-7-amino-4methylcoumarin for LAP (Saiya-Cork et al., 2002).

The soil $(1 \mathrm{~g})$ was suspended in $125 \mathrm{ml}$ of $50 \mathrm{mM}$ acetate buffer ( $\mathrm{pH}$ 5.0). The suspensions were stirred using a magnetic stir plate to ensure thorough mixing. A subsample of the soil suspension $(0.2 \mathrm{ml})$ was dispensed into 96-well microplates, and 8 replicate wells were employed per sample per-assay. Fifty microliters of $200 \mathrm{mM}$ substrate solution was also added to each sample well. The microplate was incubated in the dark at $20^{\circ} \mathrm{C}$ for $4 \mathrm{~h}$, and $10 \mu \mathrm{l}$ of $1.0 \mathrm{M} \mathrm{NaOH}$ was then added to the microplate to stop the reaction before measuring the fluorescence using a microplate fluorometer (Synergy H4, BioTek) with $365 \mathrm{~nm}$ excitation and $450 \mathrm{~nm}$ emission filters. Replicate blank, negative control and quench standard wells were also measured. The enzyme activities were calculated according to German et al. (2011) and are expressed as nmol of MUF released per $g$ soil and hour $\left(\right.$ nmol g $\left.{ }^{-1} h^{-1}\right)$.

\subsection{Statistical analysis}

The PLFAs patterns were subjected to a principal component analysis (PCA). The mole percent of individual fatty acids was used in PLFAs pattern analysis according to Bossio and Scow (1998) and Bowles et al. (2014). A permutational multivariate analysis of variance (PERMANOVA) revealed the effect of experimental treatments on the overall microbial community structure (Anderson, 2005). The MonteCarlo test was performed to test the significance of the effects of all measured SOM fractions on the community structure using Canoco software. These SOM fractions included SOC, TN, DOC, DON, POC and PON.

The SOM content, enzyme activity and metabolic function data were analyzed using a two-way ANOVA with SAS (SAS Inc. 1996). A two-way 
analysis of variance (ANOVA) was also used to examine the contribution (\%) of BC and fertilization effects on the soil SOM content, enzyme activities, abundance of microbial groups and microbial metabolic functions. Differences were considered significant at $p<0.05$, with a separation of mean values by a least significant difference (LSD) test.

\section{Results}

\subsection{Soil $C$ and $N$ fractions}

The application of BC showed dominant effects on the content of all SOM fractions except PON (Table 1). The total soil $C$ content increased by $48.9 \%$ after BC amendment (BC, BC-NPK) $(p<0.05$, Fig. 1 and Table 1). The DOC and DON concentrations were $18.7-41.0 \%$ higher after BC-NPK application compared with CK or NPK application alone ( $p<0.05$, Fig. 1 and Table 1 ). The POC content was 2.7-3.9 times higher after BC and BC-NPK applications than after CK or NPK application alone $(p<0.05$, Fig. 1 and Table 1$)$. Although the POC was mainly affected by BC application, the PON was primarily affected by fertilizer application (up to $62.5 \%$ variation) (Table 1 ). Specifically, the PON content was approximately 1.4 times higher after fertilizer application (NPK, BC-NPK) compared to the CK treatment ( $p<0.05$, Fig. 1 and Table 1 ). Although the $\mathrm{C}$ and $\mathrm{N}$ fractions were consistently higher in either the $\mathrm{BC}$ or the BC-NPK paddy than in the CK paddy, none of the measured SOM fractions significantly differed between BC and BC-NPK treatments $(p>0.05$, Fig. 1 and Table 1$)$.

\subsection{Microbial community structure}

Fertilizer application significantly affected the abundance of microbial groups and the patterns of the microbial community (Table 1 , Fig. 2 and Fig. 3A). The total PLFA abundance increased by $26.1-49.3 \%$ after fertilizer application (NPK, BC-NPK) ( $p<0.05$; Table 1 and Fig. 2). NPK application (NPK, BC-NPK) also increased the abundance of bacterial communities, specifically $38.2 \%$ and $13.9 \%$ higher $\mathrm{G}(-$ ) PLFAs than
CK and BC, respectively ( $p<0.05$; Table 1 and Fig. 2 ). Fungi and actinomycetes were 43.9-70.4\% and 21.2-64.7\% more abundant, respectively, after NPK fertilizer application (NPK, BC-NPK) than without fertilizer amendment (CK, BC) $(p<0.05$; Table 1 and Fig. 2). The PCA plot showed that the PLFA composition after fertilization (NPK, BC-NPK) significantly differed from that of the unfertilized treatments $(\mathrm{CK}, \mathrm{BC})$ (PERMANOVA test; Fig. 3A). Also the soil microbial community was significantly differed between NPK and BC-NPK treatments (PERMANOVA test; Fig. 3A). The PC1 and PC2 components accounted for $44.3 \%$ and $26.6 \%$ of the total variance, respectively (Fig. 3A).

The correlations between microbial community structure and SOM fractions (analyzed by the RDA plot) indicated that the RD1 and RD2 components accounted for $24.6 \%$ and $21.7 \%$ of the total variance (Fig. 3B). All SOM fractions explained 55\% of the variance in the PLFA-related structure of the microbial community (Monte Carlo permutation test). Among all SOM fractions, the PON explained the largest significant variation in the community structure (18\%) $(p=0.04)$.

\subsection{Enzymes activities}

Fertilizer application more significantly affected the $\beta G$ and $\beta X$ activities than BC amendment, accounting for approximately $80 \%$ of the variation (Table 1 ). The $\beta G$ and $\beta x$ activities for the BC-NPK and NPK treatments were 1.5 and 2.1 times higher than for the $\mathrm{CK}$ and $\mathrm{BC}$ treatments, respectively ( $p<0.05$; Table 1 and Fig. 4 ). Fertilization also increased the NAG activity, especially in combination with BC amendment ( $p<0.05$; Table 1 and Fig. 4$)$. Similarly, the CBH activity was mainly increased by NPK fertilization (51.9\%) (Table 1 ). The lowest $\mathrm{CBH}$ activity was observed after the application of only $\mathrm{BC}(p<0.05$; Table 1 and Fig. 4).

The LAP activity significantly differed from that of C-cycling enzymes, showing a different response of the $\mathrm{N}$ cycle to $\mathrm{BC}$ addition compared to the enzymes responsible for $C$. The application of $B C$ contributed $70 \%$ of the variation in LAP activity, whereas the

Table 1

Results of two-way ANOVA analyses on the effects of biochar and NPK fertilization on soil chemical and biological parameters.

\begin{tabular}{|c|c|c|c|c|c|c|}
\hline \multirow[t]{2}{*}{ Source of variation/factors } & \multicolumn{2}{|l|}{ Biochar } & \multicolumn{2}{|c|}{ Fertilization } & \multicolumn{2}{|c|}{ Interaction } \\
\hline & $F$ value & Contribution (\%) ${ }^{\mathrm{a}}$ & $F$ value & Contribution (\%) & $F$ value & Contribution (\%) \\
\hline \multicolumn{7}{|l|}{ SOM fractions } \\
\hline $\mathrm{SOC}\left(\mathrm{g} \mathrm{C} \mathrm{kg}^{-1}\right)$ & 88.1 & 88.2 & 0.01 & 0.02 & 0.13 & 0.14 \\
\hline $\mathrm{DOC}(\mathrm{mg} \mathrm{C} \mathrm{kg}-1)$ & 8.89 & 49.1 & 1.51 & 5.50 & 0.64 & 3.50 \\
\hline $\mathrm{DON}\left(\mathrm{mg} \mathrm{N} \mathrm{kg}^{-1}\right)$ & 17.8 & 64.3 & 1.51 & 5.50 & 0.63 & 2.30 \\
\hline $\mathrm{POC}\left(\mathrm{g} \mathrm{C} \mathrm{kg}^{-1}\right)$ & 95.5 & 92.8 & 0.21 & 0.20 & 0.89 & 0.86 \\
\hline $\mathrm{PON}\left(\mathrm{g} \mathrm{N} \mathrm{kg}^{-1}\right)$ & 0.77 & 3.70 & 13.1 & 62.5 & 0.96 & 4.56 \\
\hline \multicolumn{7}{|l|}{ Microbial groups ( $\mathrm{nmol} \mathrm{g}^{-1}$ ) } \\
\hline Total PLFAs & 4.78 & 5.54 & 66.9 & 77.5 & 8.06 & 9.34 \\
\hline Bacterial PLFAs & 4.49 & 4.10 & 88.9 & 81.2 & 9.48 & 8.66 \\
\hline Fungi PLFAs & 4.82 & 8.99 & 40.9 & 75.4 & 0.58 & 1.09 \\
\hline$G(+)$ PLFAs & 0.98 & 0.64 & 133.2 & 87.7 & 10.4 & 6.86 \\
\hline $\mathrm{G}(-)$ PLFAs & 3.7 & 11.8 & 19.4 & 61.9 & 2.09 & 6.65 \\
\hline Actinomycetes PLFAs & 2.3 & 10.0 & 10.5 & 45.7 & 3.08 & 13.2 \\
\hline \multicolumn{7}{|l|}{ Soil enzymes ( $\left.\mathrm{nmol} \mathrm{g}^{-1} \mathrm{~h}^{-1}\right)$} \\
\hline$\beta G$ & 0.27 & 0.7 & 31.5 & 79.9 & 1.25 & 3.19 \\
\hline$\beta X$ & 0.36 & 0.68 & 42.7 & 80.7 & 3.25 & 6.14 \\
\hline $\mathrm{CBH}$ & 19.1 & 17.8 & 55.9 & 51.9 & 22.3 & 20.8 \\
\hline NAG & 0.9 & 2.33 & 17.4 & 45.2 & 12.7 & 33 \\
\hline LAP & 85.4 & 70.0 & 24 & 19.6 & 6.08 & 4.98 \\
\hline \multicolumn{7}{|l|}{ Metabolic function } \\
\hline AWCD & 14.2 & 43.2 & 3.86 & 11.8 & 5.73 & 17.4 \\
\hline Amino acids & 33.6 & 35.8 & 1.27 & 3.69 & 1.55 & 0.15 \\
\hline Amines & 59.6 & 34.8 & 0.12 & 3.3 & 14.1 & 19.7 \\
\hline
\end{tabular}

Significant contribution at $p<0.05$ or $p<0.01$ is shown in bold.

a The contribution (\%) means the percentage of each factor for explaining overall variance. 

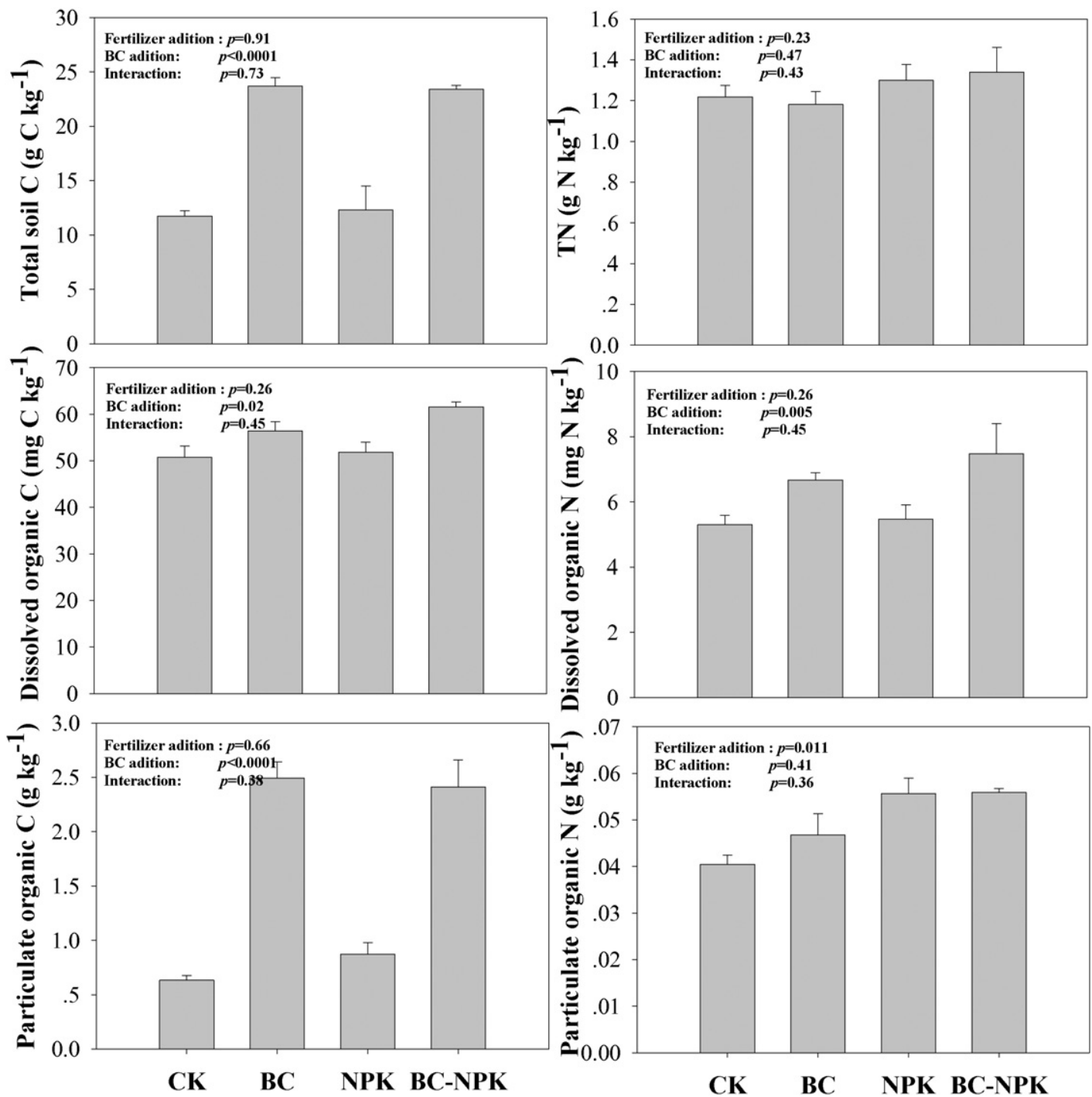

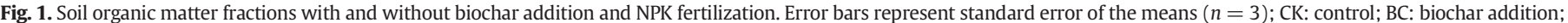
NPK: NPK fertilizer addition; BC-NPK: combined biochar and NPK fertilizer addition.

contribution of fertilizers only accounted for $19.6 \%$ of the variation (Table 1 ). The LAP activity increased in the following order: $\mathrm{CK} \approx \mathrm{NPK}<\mathrm{BC}<\mathrm{BC}-\mathrm{NPK}(p<0.05$; Table 1 and Fig. 4$)$.

\subsection{Microbial metabolic functions}

The $\mathrm{BC}$ amendment clearly affected the microbial metabolic functions (Table 1). The addition of BC (BC, BC-NPK) increased the total metabolic activity (indicated as AWCD) by $36.2-58.4 \%$ compared with the CK and NPK treatments, but it did not affect the metabolic diversity (indicated as Shannon-Wiener, $\mathrm{H}^{\prime}$ ) (Tables 1 and 2). Remarkably, BC addition increased the microbial utilization intensity of amino acids and amines (BC, BC-NPK) $(p<0.05$; Tables 1 and 2$)$.

\section{Discussion}

\subsection{Effects of biochar and fertilizer addition on organic matter fractions}

The higher soil total $\mathrm{C}$ content after $\mathrm{BC}$ application alone or combined with fertilization (BC-NPK) compared with CK and NPK application treatments (Table 1 and Fig. 1) confirmed the role of $\mathrm{BC}$ in contributing to C storage in soil (Lehmann et al., 2006; Demisie et al., 2014). Biochar is a very C-rich substrate, and it is also resistant to decay due to its aromatic structure; e.g., only approximately $6 \%$ of the initially added $\mathrm{BC}$ was mineralized to $\mathrm{CO}_{2}$ during the first 8.5 years of incubation (Kuzyakov et al., 2014). BC application, therefore, can increase $\mathrm{C}$ stock in paddy soil.

The addition of $\mathrm{BC}$ (BC, BC-NPK) increased the POC content (Table 1 and Fig. 1). Specifically, $B C$ amendment may have directly contributed to the POC fraction in our study. A significant portion of the BC was associated with non-physically protected $\mathrm{OM}$ and $\mathrm{OM}$ occluded into aggregates after density fractionation (Llorente et al., 2010). Therefore, it is likely that a significant portion of BC is localized in the POM, thus resulting in higher content, especially for POC. Although we cannot conclusively prove this relationship because we did not extract $\mathrm{BC}$ from the POM in this study, the increased POC: PON ratio after BC addition indicated that a significant portion of $\mathrm{BC}$ might be localized in the POM fraction. POC is associated with nutrient cycling (Liebig et al., 2002), SOM sequestration (Carter and Gregorich, 2010), and the formation and stability of macro-aggregates in soil (Six et al., 2000). Our results clearly indicate that $\mathrm{BC}$ addition to soil may have a higher potential for improving soil quality. The higher DOC and DON concentrations in response to BCNPK application compared with the CK and NPK only treatment (Fig. 1) may be attributed to both the indirect $\mathrm{BC}$ effect and the synergistic effects of $B C$ and fertilization. Because the $C$ originating from litter and humus constitutes a significant proportion of DOM (Kalbitz et al., 

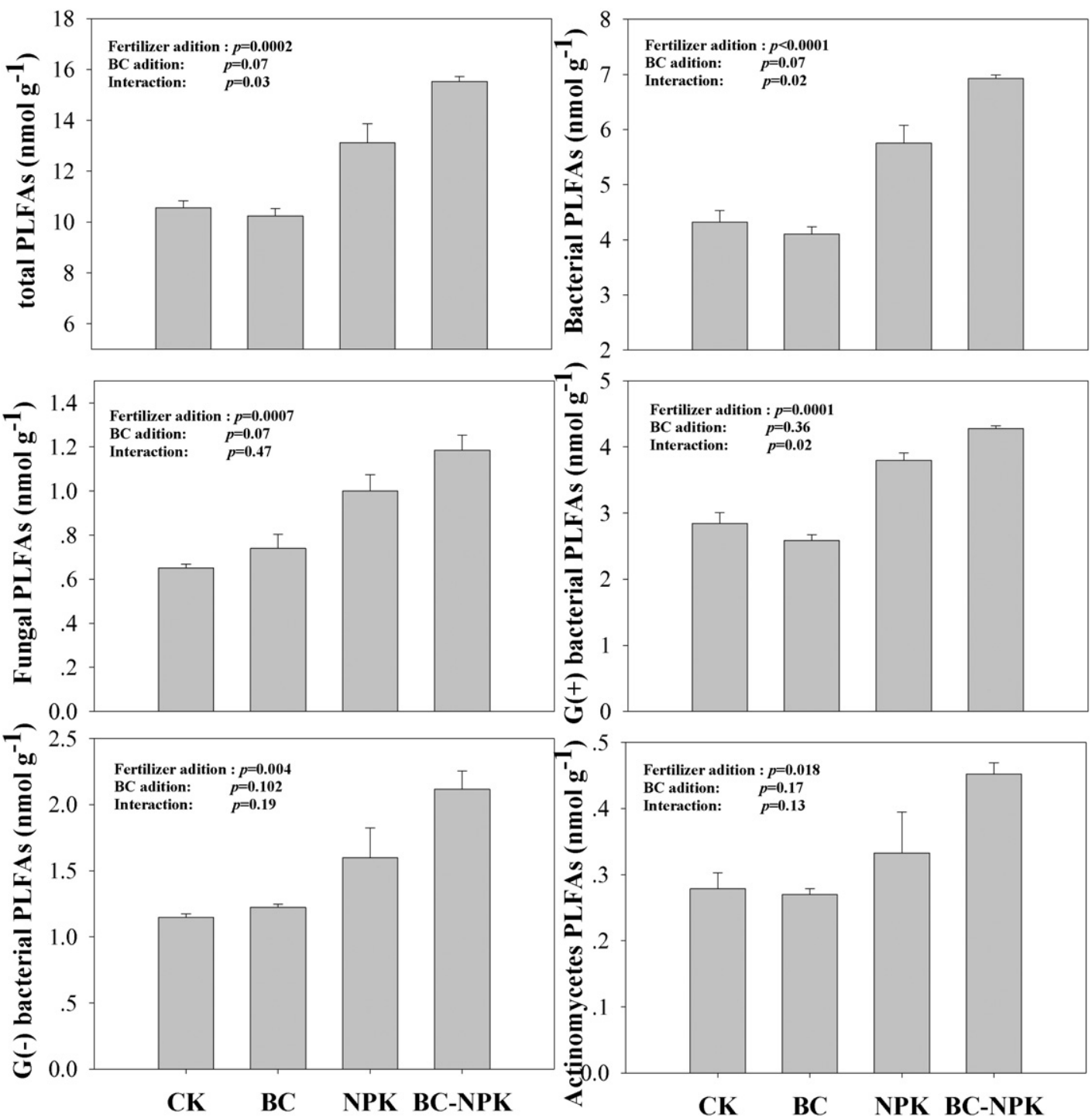

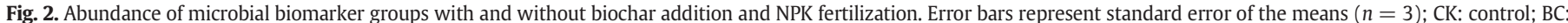
biochar addition; NPK: NPK fertilizer addition; BC-NPK: combined biochar and NPK fertilizer addition.
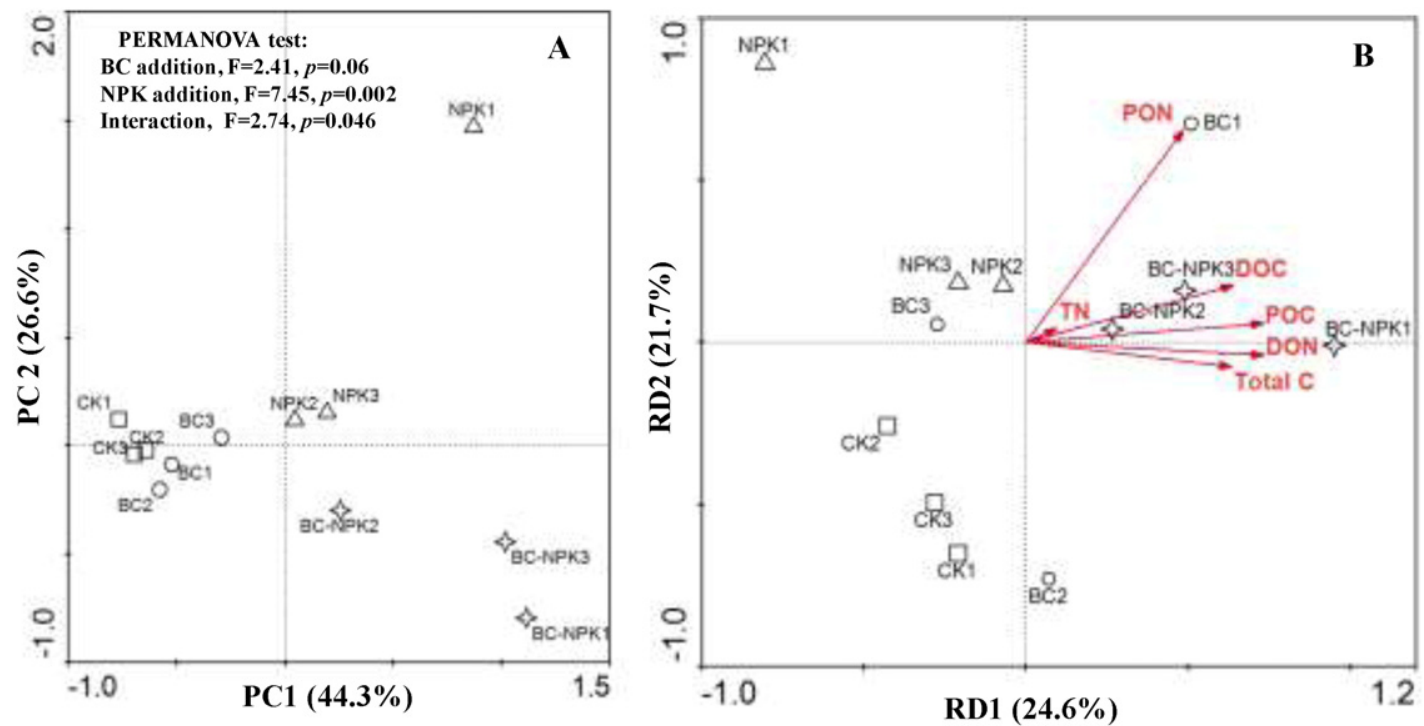

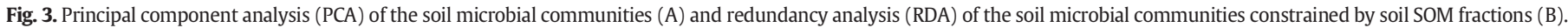




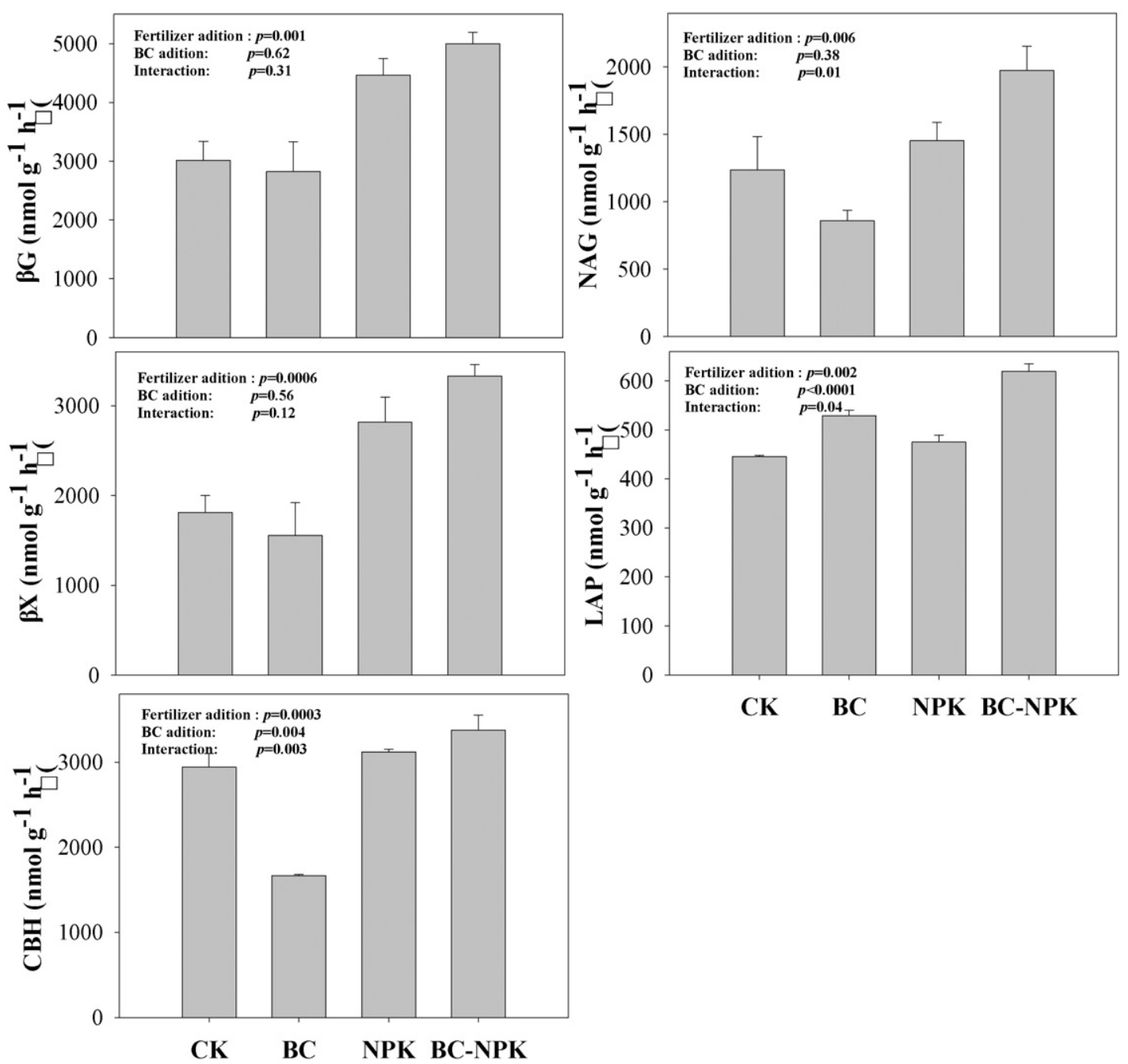

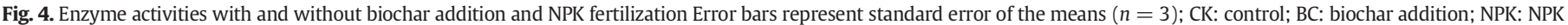
fertilizer addition; BC-NPK: combined biochar and NPK fertilizer addition.

2000; Haynes, 2005), the increase in the DOC and DON may be partly attributed to the higher plant biomass or the larger roots biomass and exudation after BC and fertilizer amendment. Indeed, the aboveground biomass was significantly higher after BC-NPK amendment than after the other three treatments (7996 $\mathrm{kg} \mathrm{ha}^{-1}$ vs. 5543, 5490, and $5623 \mathrm{~kg} \mathrm{ha}^{-1}$ ). According to our results, the combined application of BC and NPK (BC-NPK treatment) could be a promising sustainable agricultural management strategy than BC only addition. Specifically, BC and fertilization synergistically interact to accumulate and sequester $C$ and enhance SOM cycling.
4.2. Effects of biochar and fertilizer addition on microbial community structure

Fertilizer was the main factor influencing microbial abundance and community structure (Table 1, Fig. 2 and Fig. 3A). This observation was supported by a meta-analysis that revealed a $15.1 \%$ increase in microbial biomass after mineral fertilizers application (Geisseler and Scow, 2014). Interestingly, compared with the $\mathrm{CK}$, the addition of only BC did not change microbial abundance and community structure. However, $\mathrm{BC}$ altered the microbial abundances and community structure in

Table 2

Microbial metabolic activity (AWCD), Shannon-Wiener diversity $\left(\mathrm{H}^{\prime}\right)$ and microbial utilization of $\mathrm{C}$ substrates with and without biochar addition and NPK fertilization.

\begin{tabular}{|c|c|c|c|c|c|c|c|c|}
\hline \multirow[t]{2}{*}{ Treatment } & \multirow[t]{2}{*}{ AWCD } & \multirow[t]{2}{*}{ Shannon-Wiener diversity $\left(\mathrm{H}^{\prime}\right)$} & \multicolumn{6}{|c|}{ Intensity of substrates utilization } \\
\hline & & & Carbohydrates & Carboxylic acids & Amino acids & Amines & Polymers & Miscellaneous \\
\hline CK & $0.77(0.04)$ & $2.95(0.07)$ & $6.60(1.59)$ & $7.51(0.19)$ & $4.24(0.40)$ & $1.41(0.14)$ & $3.39(0.36)$ & $1.67(0.15)$ \\
\hline $\mathrm{BC}$ & $1.22(0.14)$ & $3.05(0.03)$ & $5.80(0.40)$ & $7.96(0.78)$ & $9.08(0.47)$ & $2.72(0.11)$ & $4.00(0.97)$ & $1.70(0.46)$ \\
\hline NPK & $0.80(0.03)$ & $2.90(0.04)$ & $4.62(0.52)$ & $6.64(1.11)$ & $4.32(0.41)$ & $1.87(0.14)$ & $4.48(0.40)$ & $1.84(0.06)$ \\
\hline BC-NPK & $1.09(0.18)$ & $3.06(0.03)$ & $4.77(0.25)$ & $8.32(1.43)$ & $7.45(1.40)$ & $2.33(0.03)$ & $3.63(0.59)$ & $1.54(0.05)$ \\
\hline
\end{tabular}

Numbers in bracket represent standard error of the means $(n=3)$.

CK: control; BC: biochar addition; NPK: NPK fertilizer addition; BC-NPK: combined biochar and NPK fertilizer addition. 
conjunction with NPK fertilization (BC-NPK) (Fig. 2, Fig. 3A, and Table 1). Previous studies reported an increase in bacterial abundance and altered microbial communities after BC addition under controlled laboratory conditions, which was attributed to the physic-chemical properties of BC (e.g., sorption, $\mathrm{pH}$, chemical properties, habitats) (Anderson et al., 2011; Hale et al., 2015; Pietikäinen et al., 2000). However, such short-term positive effects of the physico-chemical properties of BC on microorganisms under controlled laboratory conditions were not as notable in our long-term field study. The altered microbial community under BC-NPK vs. BC can partly be attributed to $\mathrm{N}$ limitation for crops and microbial $\mathrm{N}$ immobilization caused by sole $\mathrm{BC}$ addition (Nelissen et al., 2012; Steiner et al., 2008). Inorganic fertilizer addition may reduce $\mathrm{N}$ limitation for crop and weaken plant-microbial competition for $\mathrm{N}$, therefore improving crop growths and affecting microorganisms by direct mineral nutrients input and indirect crop effects under BC-NPK treatment. This agrees with previous studies that showed that higher plant biomass usually induced higher SOM fractions contents (e.g., particulate organic matter, rhizodeposition), which could act as major sources and energy for microorganism (Haynes, 2005; Tian et al., 2013). Higher abundances of microbial groups under BC-NPK conditions coincide with higher aboveground biomass in our field study. This response also corresponds to our finding that changes in PON were the main SOM fractions for influencing the microbial community (Fig. 3B). Previous reports showed that particulate organic matter was the primary source of mineral N (Zeller and Dambrine, 2011).

In addition to the main effects of fertilizer (by direct mineral nutrients input and indirect crop effect) on microorganisms, a synergic positive BC effect on microorganisms under BC-NPK treatment resulted in a $15.5 \%$ higher total microbial biomass and $17.0 \%$ higher bacterial biomass in BC-NPK vs. NPK treatment. This may be attributed to improved N fertilizer use efficiency by BC addition (Steiner et al., 2008), thus leading to better amplified fertilizer effects compared with only NPK addition. Similar to our study, Doan et al. (2014) observed a 59\% greater bacterial abundance after combination of $\mathrm{BC}$ and inorganic $\mathrm{N}$ application compared with only mineral fertilizer addition in a 3-year mesocosm study. Thus, the hypothesized synergistic effects of $\mathrm{BC}$ and mineral fertilizers on microorganisms were confirmed by pronounced increase in microbial populations under BC-NPK treatment.

\subsection{Effects of biochar and fertilizer addition on soil enzymes and metabolic microbial functions}

In contrast to the increase in the peptidase activity (LAP) after only $\mathrm{BC}$ application, the activity of enzymes that decompose plant residues slightly ( $\beta G$ and $\beta X$ ) or significantly (CBH) decreased (Fig. 4). Furthermore, the decrease of $\beta \mathrm{G}$ and $\mathrm{CBH}$ activities by $\mathrm{BC}$ positively correlated with the BC application rate (Jin, 2010; Bailey et al., 2011). This decrease in the activity of $\mathrm{C}$-cycling enzymes after $\mathrm{BC}$ application alone may be ascribed to the co-localization of $\mathrm{C}$ and microorganisms on the $\mathrm{BC}$ surfaces, which may improve the carbon use efficiency and reduce the need for enzyme production (Lehmann et al., 2011). It should be noted that the decreased enzymes activities (e.g. $\beta G$ ) could also be caused by BC sorption (Lammirato et al., 2011). However, a decrease in enzyme activity by mere sorption to biochar is less likely, as suggested by Lehmann et al. (2011). Nevertheless, it is important to consider reducing sorption-driven artificial phenomenon in order to most accurately report the activities of soil enzymes in the presence of $\mathrm{BC}$ in future studies. For example, Bailey et al. (2011) strongly recommend the use of fluorescence-based assays for measuring enzymes activities in BC-related studies.

Interestingly, the combined application of NPK and BC significantly increased the $\mathrm{C}$-cycling enzyme activities compared with the application of $\mathrm{BC}$ alone, confirming our hypothesis. This finding may be attributed to increased microbial turnover induced by NPK fertilization, which over-compensates for the effect of BC-NPK treatment. Thus, sole application of $\mathrm{BC}$ may cause low soil $\mathrm{C}$ mineralization and nutrient cycling; however, inorganic fertilizer amendment will compensate for this shortage.

Although the Shannon-Wiener index was not affected, BC application increased the metabolic activity, which affected the substrate utilization pattern. The altered substrate utilization pattern, as indicated by an increase in the utilization of amino acids and amines (Table 2), reflects that microbes mine the SOM for $\mathrm{N}$ to compensate for the high C:N ratio after BC amendment. Similarly, a 10\% greater utilization of amino acids was observed after the addition of complex substrates (with high C:N) compared with the addition of simple compounds (with low C:N) (Orwin et al., 2006). Nevertheless, the accelerated utilization of $\mathrm{N}$ compounds caused by BC in our study (up to 50\%) was much more pronounced than the $10 \%$ increase observed by Orwin et al. (2006). This was evidently because the complexity of the substrate directly correlates with the number of enzymes required for its degradation. Therefore, the utilization of the complex BC substrate required more N. Similar to our observations, the substrate use pattern of microorganisms changed after BC addition in a forest organic soil horizon (Pietikäinen et al., 2000), and these changes were attributed to the microbial community structure and enzyme activities. The latter is supported by our results because the altered substrate utilization pattern after $\mathrm{BC}$ amendment was mainly due to changes in the soil peptidase activity (LAP).

\section{Conclusions}

The addition of BC alone did not alter the structure of the soil microbial community, but it significantly increased the peptidase activity to accelerate the decomposition of soil proteins. Therefore, the $\mathrm{BC}$ management strategy may accelerate organic $\mathrm{N}$ turnover and consequently has important implications for $\mathrm{N}$ cycling in agricultural ecosystems. If $\mathrm{BC}$ application induces $\mathrm{N}$ limitation for crops and microbial $\mathrm{N}$ immobilization, NPK fertilization could compensate for these negative effects on the SOM and microbial turnover. Further studies are required to determine the trade-off in $\mathrm{N}$ uptake between microorganisms and crops after $\mathrm{BC}$ and NPK fertilization by using long-term field plots. Furthermore, future studies are necessary to investigate the impact of $\mathrm{BC}$ and fertilization on the dynamics of microbial community and functions and the interactions between SOM and the microorganisms.

\section{Acknowledgements}

We thank the National Natural Science Foundation of China (Grant No. 31400460) and the Major Program of National Natural Science Foundation of China (Grant Nos. 31420103917 and 30290221) for their generous financial support. The contribution of EB was supported by the Russian Science Foundation (project No. 14-14-00625).

\section{References}

Anderson, M.J., 2005. PERMANOVA: A FORTRAN Computer Program for Permutational Multivariate Analysis of Variance. Department of Statistics, University of Auckland, New Zealand.

Anderson, C.R., Condron, L.M., Clough, T.J., Fiers, M., Stewart, A., Hill, R.A., Sherlock, R.R., 2011. Biochar induced soil microbial community change: implications for biogeochemical cycling of carbon, nitrogen and phosphorus. Pedobiologia 54, 309-320.

Atkinson, C.J., Fitzgerald, J.D., Hipps, N.A., 2010. Potential mechanisms for achieving agricultural benefits from biochar application to temperate soils: a review. Plant Soil 337, $1-18$.

Bailey, V.L., Fansler, S.J., Smith, J.L., Bolton, H., 2011. Reconciling apparent variability in effects of biochar amendment on soil enzyme activities by assay optimization. Soil Biol. Biochem. 43, 296-301.

Balser, T.C., Firestone, M.K., 2005. Linking microbial community composition and soil processes in a California annual grassland and mixed-conifer forest. Biogeochemistry 73, 395-415.

Bolan, N.S., Kunhikrishnan, A., Choppala, G.K., Thangarajan, R., Chung, J.W., 2012. Stabilization of carbon in composts and biochars in relation to carbon sequestration and soil fertility. Sci. Total Environ. 424, 264-270.

Bossio, D.A., Scow, K.M., 1998. Impacts of carbon and flooding on soil microbial communities: phospholipid fatty acid profiles and substrate utilization patterns. Microb. Ecol. 35, 265-278. 
Bowles, T.M., Acosta-Martínez, V., Calderón, F., Jackson, L.E., 2014. Soil enzyme activities, microbial communities, and carbon and nitrogen availability in organic agroecosystems across an intensively-managed agricultural landscape. Soil Biol. Biochem. 68, 252-262.

Cambardella, C.A., Elliott, E.T., 1992. Particulate soil organic matter changes across a grassland cultivation sequence. Soil Sci. Soc. Am. J. 56, 777-783.

Carter, M.R., Gregorich, E.G., 2010. Carbon and nitrogen storage by deep-rooted tall fescue (Lolium arundinaceum) in the surface and subsurface soil of a fine sandy loam in eastern Canada. Agric. Ecosyst. Environ. 136, 125-132.

Chen, J.H., Liu, X.Y., Zheng, J.W., Zhang, B., Lu, H.F., Chi, Z.Z., Pan, G.X., Li, L.Q., Zheng, J.F., Zhang, X.H., Wang, J.F., Yu, X.Y., 2013. Biochar soil amendment increased bacterial but decreased fungal gene abundance with shifts in community structure in a slightly acid rice paddy from Southwest China. Appl. Soil Ecol. 71, 33-44.

Clemmensen, K.E., Bahr, A., Ovaskainen, O., Dahlberg, A., Ekblad, A., Wallander, H., Stenlid, J., Finlay, R.D., Wardle, D.A., Lindahl, B.D., 2013. Roots and associated fungi drive longterm carbon sequestration in boreal forest. Science 339, 1615-1618.

Demisie, W., Liu, Z., Zhang, M., 2014. Effect of biochar on carbon fractions and enzyme activity of red soil. Catena 121, 214-221.

Doan, T.T., Bouvier, C., Bettarel, Y., Bouvier, T., Henry-des-Tureaux, T., Janeau, J.L., Lamballe, P., Nguyen, B.V., Jouquet, P., 2014. Influence of buffalo manure, compost vermicompost and biochar amendments on bacterial and viral communities in soil and adjacent aquatic systems. Appl. Soil Ecol. 73, 78-86.

Farrell, M., Kuhn, T.K., Macdonald, L.M., Maddern, T.M., Murphy, D.V., Hall, P.A., Singh, B.P., Baumann, K., Krull, E.S., Baldock, J.A., 2013. Microbial utilisation of biochar-derived carbon. Sci. Total Environ. 465, 288-297.

Farrell, M., Macdonald, L.M., Baldock, J.A., 2015. Biochar differentially affects the cycling and partitioning of low molecular weight carbon in contrasting soils. Soil Biol. Biochem. 80, 79-88.

Frostegård, Á., Tunlid, A., Bååth, E., 1991. Microbial biomass measured as total lipid phosphate in soils of different organic content. J. Microbiol. Methods 14, 151-163.

Frostegård, Å., Bååth, E., Tunlio, A., 1993. Shifts in the structure of soil microbial communities in limed forests as revealed by phospholipid fatty acid analysis. Soil Biol. Biochem. 25, 723-730.

Garland, J.L., Mills, A.L., 1991. Classification and characterization and characterization of heterotrophic microbial communities on the basis of patterns of community-level sole-carbon-level. Appl. Environ. Microbiol. 57, 2351-2359.

Geisseler, D., Scow, K.M., 2014. Long-term effects of mineral fertilizers on soil microorganisms - a review. Soil Biol. Biochem. 75, 54-63.

German, D.P., Weintraub, M.N., Grandy, A.S., Lauber, C.L., Rinkes, Z.L., Allison, S.D., 2011. Optimization of hydrolytic and oxidative enzyme methods for ecosystem studies. Soil Biol. Biochem. 43, 1387-1397.

Gul, S., Whalen, J.K., Thomas, B.W., Sachdeva, V., Deng, H.Y., 2015. Physico-chemical properties and microbial responses in biochar-amended soils: mechanisms and future directions. Agric. Ecosyst. Environ. 206, 46-59.

Hale, L., Luth, M., Crowley, D., 2015. Biochar characteristics relate to its utility as an alternative soil inoculum carrier to peat and vermiculite. Soil Biol. Biochem. 81, 228-235.

Haynes, R.J., 2005. Labile organic matter fractions as central components of the quality of agricultural soils: an overview. In: Sparks, D.L. (Ed.), Advances in Agronomy. Vol Vol. 85 , pp. 221-268.

Jin, H., 2010. Characterization of microbial life colonizing biochar and biochar-amended soils. PhD Dissertation. Cornell University, Ithaca, NY.

Jindo, K., Sánchez-Monedero, M.A., Hernández, T., Garcia, C., Furukawa, T., Matsumoto, K. Sonoki, F.B., 2012. Biochar influences the microbial community structure during manure composting with agricultural wastes. Sci. Total Environ. 416, 476-481.

Jones, D.L., Willett, V.B., 2006. Experimental evaluation of methods to quantify dissolved organic nitrogen (DON) and dissolved organic carbon (DOC) in soil. Soil Biol. Biochem. 38, 991-999.

Jones, D.L., Rousk, J., Edwards-Jones, G., DeLuca, T.H., Murphy, D.V., 2012. Biocharmediated changes in soil quality and plant growth in a three year field trial. Soil Biol. Biochem. 45, 113-124.

Kalbitz, K., Solinger, S., Park, J.H., Michalzik, B., Matzner, E., 2000. Controls on the dynamics of dissolved organic matter in soils: a review. Soil Sci. 165, 277-304.

Kuzyakov, Y., Bogomolova, I., Glaser, B., 2014. Biochar stability in soil: decomposition during eight years and transformation as assessed by compound-specific $14 \mathrm{C}$ analysis. Soil Biol. Biochem. 70, 229-236.

Lammirato, C., Miltner, A., Kaestner, M., 2011. Effects of wood char and activated carbon on the hydrolysis of cellobiose by $\beta$-glucosidase from Aspergillus niger. Soil Biol. Biochem. 43, 1936-1942.

Lehmann, J., da Silva, J.P., Steiner, C., Nehls, T., Zech, W., Glaser, B., 2003. Nutrient availability and leaching in an archaeological anthrosol and a ferralsol of the Central Amazon basin: fertilizer, manure and charcoal amendments. Plant Soil 249, 343-357.

Lehmann, J., Gaunt, J., Rondon, M., 2006. Bio-char sequestration in terrestrial ecosystems a review. Mitig. Adapt. Strateg. Glob. Chang. 11, 395-419.
Lehmann, J., Rillig, M.C., Thies, J., Masiello, C.A., Hockaday, W.C., Crowley, D., 2011. Biochar effects on soil biota - a review. Soil Biol. Biochem. 43, 1812-1836.

Liang, B., Lehmann, J., Sohi, S.P., Thies, J.E., O'Neill, B., Trujillo, L., Gaunt, J., Solomon, D., Grossman, J., Neves, E.G., Luizão, F.J., 2010. Black carbon affects the cycling of nonblack carbon in soil. Org. Geochem. 41, 206-213.

Liebig, M.A., Varvel, G.E., Doran, J.W., Wienhold, B.J., 2002. Crop sequence and nitrogen fertilization effects on soil properties in the western Corn Belt. Soil Sci. Soc. Am. J. 66, 596-601.

Lin, Y., Munroe, P., Joseph, S., Henderson, R., Ziolkowski, A., 2012. Water extractable organic carbon in untreated and chemical treated biochars. Chemosphere 87, 151-157.

Llorente, M., Glaser, B., Belen Turrion, M., 2010. Storage of organic carbon and black carbon in density fractions of calcareous soils under different land uses. Geoderma $159,31-38$

Lu, W., Ding, W., Zhang, J., Li, Y., Luo, J., Bolan, N., Xie, Z., 2014. Biochar suppressed the decomposition of organic carbon in a cultivated sandy loam soil: a negative priming effect. Soil Biol. Biochem. 76, 12-21.

Nelissen, V., Rutting, T., Huygens, D., Staelens, J., Ruysschaert, G., Boeckx, P., 2012. Maize biochars accelerate short-term soil nitrogen dynamics in a loamy sand soil. Soil Biol. Biochem. 55, 20-27.

Ng, E.-L., Patti, A.F., Rose, M.T., Schefe, C.R., Wilkinson, K., Smernik, R.J., Cavagnaro, T.R., 2014. Does the chemical nature of soil carbon drive the structure and functioning of soil microbial communities? Soil Biol. Biochem. 70, 54-61.

Orwin, K.H., Wardle, D.A., Greenfield, L.G., 2006. Ecological consequences of carbon substrate identity and diversity in a laboratory study. Ecology 87, 580-593.

Pietikäinen, J., Kiikkila, O., Fritze, H., 2000. Charcoal as a habitat for microbes and its effect on the microbial community of the underlying humus. Oikos 89, 231-242.

Preston-Mafham, J., Boddy, L., Randerson, P.F., 2002. Analysis of microbial community functional diversity using sole-carbon-source utilization profiles - a critique. FEMS Microbiol. Ecol. 42, 1-14.

Prommer, J., Wanek, W., Hofhansl, F., Trojan, D., Offre, P., Urich, T., Schleper, C., Sassmann, S., Kitzler, B., Soja, G., Hood-Nowotny, R.C., 2014. Biochar decelerates soil organic nitrogen cycling but stimulates soil nitrification in a temperate arable field trial. PLoS One 9.

Rillig, M.C., Wagner, M., Salem, M., Antunes, P.M., George, C., Ramke, H.-G., Titirici, M.-M., Antonietti, M., 2010. Material derived from hydrothermal carbonization: effects on plant growth and Arbuscular mycorrhiza. Appl. Soil Ecol. 45, 238-242.

Saiya-Cork, K.R., Sinsabaugh, R.L., Zak, D.R., 2002. The effects of long term nitrogen deposition on extracellular enzyme activity in an Acer saccharum forest soil. Soil Biol. Biochem. 34, 1309-1315.

Six, J., Elliott, E.T., Paustian, K., 2000. Soil macroaggregate turnover and microaggregate formation: a mechanism for $C$ sequestration under no-tillage agriculture. Soil Biol. Biochem. 32, 2099-2103.

Steiner, C., Teixeira, W., Lehmann, J., Nehls, T., de Macêdo, J., Blum, W.H., Zech, W., 2007. Long term effects of manure, charcoal and mineral fertilization on crop production and fertility on a highly weathered Central Amazonian upland soil. Plant Soil 291, 275-290.

Steiner, C., Glaser, B., Geraldes Teixeira, W., Lehmann, J., Blum, W.E.H., Zech, W., 2008. Nitrogen retention and plant uptake on a highly weathered central Amazonian ferralsol amended with compost and charcoal. J. Plant Nutr. Soil Sci. 171, 893-899.

Stevenson, F.J., 1994. Humus Chemistry: Genesis, Composition. Reactions. John Wiley \& Sons, New York, p. 496.

Tian, J., Dippold, M., Pausch, J., Blagodatskaya, E., Fan, M., Li, X., Kuzyakov, Y., 2013. Microbial response to rhizodeposition depending on water regimes in paddy soils. Soil Biol. Biochem. 65, 195-203.

von Lützow, M., Kögel-Knabner, I., Ekschmitt, K., Flessa, H., Guggenberger, G., Matzner, E., Marschner, B., 2007. SOM fractionation methods: relevance to functional pools and to stabilization mechanisms. Soil Biol. Biochem. 39, 2183-2207.

Wardle, D.A., Nilsson, M.-C., Zackrisson, O., 2008. Fire-derived charcoal causes loss of forest humus. Science 320, 629

Xu, H.-J., Wang, X.-H., Li, H., Yao, H.-Y., Su, J.-Q., Zhu, Y.-G., 2014. Biochar impacts soil microbial community composition and nitrogen cycling in an acidic soil planted with rape. Environ. Sci. Technol. 48, 9391-9399.

Zak, J.C., Willig, M.R., Moorhead, D.L., Wildman, H.G., 1994. Functional diversity of microbial communities-a quantitative approach. Soil Biol. Biochem. 26, 1101-1108.

Zeller, B., Dambrine, E., 2011. Coarse particulate organic matter is the primary source of mineral $\mathrm{N}$ in the topsoil of three beech forests. Soil Biol. Biochem. 43, 542-550.

Zelles, L., 1997. Phospholipid fatty acid profiles in selected members of soil microbial communities. Chemosphere 35, 275-294.

Zelles, L., 1999. Fatty acid patterns of phospholipids and lipopolysaccharides in the characterisation of microbial communities in soil: a review. Biol. Fertil. Soils 29, 111-129. 